\title{
JENIS DAN POPULASI LALAT PADA TERNAK SAPI DI DESA TOLOK, KECAMATAN TOMPASO, KABUPATEN MINAHASA
}

\author{
Faris Djenaan, G. J. V. Assa*, Z. Poli, A. Lomboan.
}

Fakultas Peternakan Universitas Sam Ratulangi Manado

\begin{abstract}
ABSTRAK
Penelitian jenis dan populasi lalat pada ternak sapi di desa Tolok Kecamatan Tompaso Kabupaten Minahasa telah di laksanakan selama 1(satu) bulan menggunakan ternak sapi sejumlah 16 ekor - Pada penelitian ini, lalat di tangkap dengan menggunakan tangguk serangga, tiap 2 minggu selama 3 kali.Hasil dari pengamatan yaitu hanya mendapatkan 3 jenis lalat yaitu Haematobia exigua, Stomoxys Calcitrans dan Musc domestica. Jumlah populasi lalat yaitu Haematobia exigua yang tertangkap 94,43, Stomoxys Calcitrans 10,49 dan Musca domestica 7,74 lalat. Hanya terdapat 1 jenis lalat yang dominan selama periode penangkapan yaitu Haematobia exigua.
\end{abstract}

Kata kunci : Populasi lalat, tipe lalat dominan, ternak sapi.

\section{ABSTRACT}

TYPES AND POPULATION OF FLY ON BEEF CATTLE AROUND TOLOK VILLAGE AT TOMPASO DISTRICT OF MINAHASA REGENCY. The Study was conducted to evaluate types and population of fly on beef cattle around Tolok village at Tompaso district of Minahasa regency. Observation was applied during a month involving sixteen beef cattle. Flies were cached using

\footnotetext{
*Korespondensi (corresponding Author) Email:
}

insect net one time on every two weeks. Collections of flies were conducted three times and types of fly were also identified including their population. Results of observation showed that there were three types fly on beef cattle including Haematobia exigua, Stomoxys Calcitrans and Musca domestica. The population of these flies were Haematobia exigua of 94.43 individuals, Stomoxys Calcitrans of 10.49 individuals and Musca domestica of 7.74 individuals. The dominant fly during collection at Tolok village was type of Haematobia exigua.

Key words: Fly population, dominating fly type, beef cattle.

\section{PENDAHULUAN}

Sistim pemeliharaan ternak sapi di Sulawesi Utara umumnya digembalakan sekitar pukul 07.00-17.00 di ladang kering atau di bawah pohon kelapa baik musim hujan maupun musim kemarau. Pola penggembalaan ternak sapi seperti yang dilakukan petani kurang memperhatikan kesehatan ternak terutama kesehatan tubuh. Sapi yang digembalakan kesehatannya kurang diperhatikan dan seringkali menimbulkan reaksi di mana ternak menggarukkan badannya pada benda- 
benda keras. Desa Tolok, Kecamatan Tompaso, Kabupaten Minahasa cukup banyak peternakan rakyat yang memelihara sapi secara ekstensif atau tradisional. Pada umumnya sapi dalam kondisi kurus dan ditemukan luka pada bagian tubuh.

Peternakan yang berkembang saat ini tidak hanya peternakan besar,namun juga peternakan tradisional. Peternakan tradisional biasanya dikelola masyarakat perseorangan dengan jumlah sapi yang berbeda-beda. Peternakan tersebut berbeda dalam jumlah sapi yang dipelihara, tujuan dan manajemen pemeliharaannya. Peternak tradisional biasanya kurang memerhatikan kebersihan ternak dan kandang. Tumpukan kotoran ternak pada kandang dapat mengundang serangga, misalnya lalat yang dapat menimbulkan gangguan bagi ternak. Lalat dapat menjadi perantara bagi agen penyakit ternak.

Selain masalah kesehatan, gangguan lalat pada ternak sapi adalah masalah ekonomi. Lalat dapat menyebabkan pertambahan bobot badan sapi tidak optimal. Menurut Taylor et al. (2012), kerugian ekonomi yang diakibatkan oleh gangguan lalat pada industri sapi di Amerika Serikat adalah 2.211 juta dollar per tahun. Kerugian ini diakibatkan oleh Stomoxys calcitrans. Keberadaan lalat tersebut menyebabkan penurunan produksi susu sekitar 139 liter/sapi/tahun dan penurunan bobot badan sebesar 9 $\mathrm{kg} / \mathrm{sapi} /$ tahun pada ternak sapi.

\section{MATERI DAN METODE PENELITIAN}

Penelitian ini dilaksanakan selama 2 (dua) bulan di Desa Tolok, Kecamatan Tompaso, Kabupaten Minahasa. Tahap penelitian diawali dengan penelitian selama 1 (satu) minggu, dan dilanjutkan kembali selama 6 (enam) minggu, Ternak sapi yang digunakan dalam penelitian ini berjumlah 16 ekor, milik dari petani dan peternak di Desa Tolok.

Alat dan bahan yang digunakan yaitu: alcohol $70 \%$, alat pengukur kelembaban, jaring serangga, pinset, botol koleksi, mikroskop, alat penghitung (hand counter) kamera digital dan kandang individu dari bambu.

Pengumpulan sampel lalat diambil pagi hari pukul 08.00 sebanyak 3 kali dengan selang waktu 2 minggu. Selama pengambilan sampel, kelembaban dan temperature diukur menggunakan ThermoHygrometer-Clock.

Koleksi lalat dilakukan pada pagi hari dengan menggunakan jaring serangga dengan diameter permukaan $10 \mathrm{~cm}$, ternak sapi dimasukkan kedalam kandang individu terbuat dari bambu dan diikat. Penangkapan lalat yang ada pada tubuh 
ternak sapi dengan cara mengayunkan jaring di sekitar badan sapi dan penangkapan dilakukan tiga kali selang waktu 2 minggu, selesai penangkapan sapi dikeluarkan. Jarak kandang individu dengan kelompok ternak yang menjadi objek penelitian kurang lebih 100 meter, hal ini dilakukan agar lalat yang ada pada tubuh ternak objek benar-benar lalat yang menempel pada ternak tersebut. Serangga yang masuk ke jaring dimasukkan kedalam killing bottle untuk dimatikan dengan chloroform dan dimasukkan ke dalam botol koleksi yang sudah diberi label dengan catatan nomor ternak dan waktu penangkapan.

Sampel diidentifikasi dengan mengacu pada kunci determinasi serangga (Subianto dan Sultoni, 1991), specimen lalat dipindahkan lalu dihitung.

\section{HASIL DAN PEMBAHASAN}

Hasil penelitian yang dilakukan untuk mengidentifikasi keragaman jenis lalat pada peternakan rakyat di desa Tolok Kecamatan Tompaso didapat 3 (tiga) jenis lalat yaitu Haematobia exigua, Stomoxys calcitran dan Musca domestica.

Lalat Haematobia exigua yang diperoleh sebanyak 94,43 lalat. Lalat Haematobia exigua dewasa panjangnya lebih dari 4,0 $\mathrm{mm}$ dan paling kecil diantara lalat penghisap darah Famili Muscidae.
Pada kepala ditemukan proboscis yang tertahan kedepan (berbeda dengan Musca $s p$ bertahan kebawah), berbeda Stomoxys, karena Haematobia (palpusnya kekar dan hampir sama panjang dibandingkan proboscis) sedangkan (Stomoxys palpus lebih pendek dibandingkan proboscis). Torak berwarna kelabu, juga ditemukan beberapa garis kehitaman.

Stomoxys calcitran yang diperoleh sebanyak 10,49 lalat. Ukuran tubuh Stomoxys calcitran hampir sama dengan Musca domestica, lalat ini memiliki probosis dengan tipe penusuk dan penghisap darah,

Wilayah distribusi lalat ini berada di Taiwan, Burma, China, India, Indonesia, Jepang, Filipina, Sri Lanka, dan Vietnam (Huang et al., 2007). Abdomen memiliki pola spot dengan garis tengah yang menyatu pada tergite kedua dan ketiga, serta pada tergite kesatu, kedua, dan ketiga terdapat spot horizontal panjang dan lebar (Tumrasvin dan Shinonaga, 1978).

Musca domestica yang diperoleh pada penelitian ini sebanyak 7,74 ekor lalat. Musca domestica dewasa biasanya berukuran 5,8-6,5 mm untuk jantan dan 6,5-7,5 $\mathrm{mm}$ untuk betina, toraks mempunyai empat garis hitam longitudinal di dorsal, mulutnya tumpul dengan bagian ujung labela melebar dan memiliki struktur 
seperti spons yang berfungsi untuk menyerap makanan (Hadi dan Soviana, 2000). Abdomen pada betina memiliki pola yang khas, yaitu motif abu-abu dan hitam yang bergantian di bagian dorsal midline dan kekuningan pada bagian pinggirannya (Moon, 2002).

Haematobia exigua cenderung lebih dominan populasinya dibandingkan dengan Musca domestica dan Stomoxys calcitrans. Lalat $H$. Exigua ini diidentifikasi paling banyak terdapat pada musim penghujan dengan suhu dan temperatur yang mendukung siklus hidupnya sekitar area lokasi pemeliharaan sapi. Lalat ini pada umumnya dikoleksi dari daerah kepala dan punggung sapi, hal ini sesuai dengan yang disampaikan oleh Foil dan Hogshette (1994) bahwa lalat ini melalukan aktivitas menghisap darah di daerah tanduk dan punggung sapi. Terdapat pada daerah punggung namun akan pindah ke daerah perut ketika cuaca panas (Moon, 2002).

$H$. exigua dewasa aktif menghisap darah pada siang hari dan menyerang hewan dalam jumlah besar, sehingga menyebabkan kegelisahan hewan yang berakibat penurunan baik berat badan maupun produksi susu. Lalat ini dapat dkatakan ektoparasit obligat karena hampir selalu berada pada inang, baik pada saat makan maupun istirahat. Penyakitpenyakit yang dapat ditularkan lalat ini antara lain surra (Trypanosoma evansa) dan
Habronemiasis (H. Microstoma) (Bowman 1999). Telur H. exigua diletakkan satupersatu atau kelompok berjumlah 4-6 butir pada feses sapi/ hewan besar yang segar. Dalam sekali bertelur bisa mencapai 20-24 butir dengan total telur yang dihasilkan selama hidup 400 butir. Setelah 24 jam telur menetas menjadi larva yang melalui 4-8 hari untuk menjadi pupa. Masa pupa berlangsung selama 6-8 hari. Perkembangan dari telur hingga mencapai dewasa dapat berlangsung selama 10 hari 2 minggu.

Jumlah Stomoxis calsitrans yang diperoleh jauh lebih kecil dibandingkan dengan Haematobia exigua. Spesies $S$. calcitrans ini merupakan serangga parasit yang umum ditemukan pada peternakan (Jeanbourquin, 2005). Serangga jantan maupun betina hidupnya sangat bergantung pada inangnya untuk mendapatkan cairan tubuh inangnya dengan cara menghisap inangnya. Stomoxys calcitrans biasanya menyerang bagian kaki pada sapi (Salem et al., 2012). Stomoxys calcitrans berkembangbiak pada sisa makanan, serta campuran kotoran dan urin dari sapi.

Rata-rata penyebaran lalat pada 16 ekor sapi selama pengamatan dengan kecenderungan yang sama pada seluruh sapi. Musca domestica rata-rata jenis lalat paling sedikit populasinya pada keseluruhan sapi, kondisi ini terjadi karena 
penelitian (penangkapan dilakukan jauh dari rumah penduduk. Musca domestica atau lalat rumah merupakan serangga kosmopolitan yang dapat ditemukan dimana terdapat aktivitas manusia. Lalat rumah ditemukan berkembang biak pada kotoran sapi dan pada fase imagonya sering ditemukan berada atau hinggap pada sapi, dimana lalat memakan cairan sekresi dari sapi, namun tidak merupakan serangga parasit pada sapi bali (Hadi, 2010; Halstead, 2012).

Lalat musca merupakan lalat yang dapat berperan sebagai vektor penularan penyakit pink eye, yaitu penyakit mata menular pada ternak, terutama sapi, kerbau, domba, dan kambing (Ditjennak Keswan, 2014).

Lalat rumah, Musca domestica, termasuk ke dalam famili Muscidae dan ordo Diptera subordo Cyclorappha. Musca domestica merupakan lalat rumah yang penyebarannya di seluruh dunia merupakan serangga yang keberadaan dangat dekat dengan manusia maupun hewan. Lalat ini aktif pada cuaca cerah, hangat dan kecepatan angin kurang dari 16 $\mathrm{km} / \mathrm{jam}$, ketika melakukan aktifitas suhu udara di atas $16^{\circ} \mathrm{C}$ dan puncak aktifitas pada suhu antara 25 dan $29^{\circ} \mathrm{C}$ (Peterson dan Meyer, 1978).

Pola makan dari Musca domestica adalah dengan menghisap makanan. Lalat rumah memiliki kebiasaan makan dan tempat perindukannya pada daerah yang kotor maka lalat ini berperan dalam penyebaran berbagai macam penyakit secara mekanis. Lalat rumah dapat ditemukan dalam jumlah besar di daerah peternakan, perunggasan, industri hewan yang sederhana secara tidak langsung dapat memberikan dampak bagi kesehatan hewan dan manusia (Moon, 2002). Lalat ini merupakan vektor demam tifoid, disentri, patek, antraks dan beberapa bentuk konjungtivitis Borror et al. (1996).

\section{KESIMPULAN}

Berdasarkan hasil penelitian dapat diambil kesimpulan bahwa jenis lalat yang terdapat pada peternakan rakyat di desa Tolok kecamatan Tompaso Haematobia exigua, Stomoxis calsitrans dan Musca domestica. Populasi lalat yang adalah Haematobia exigua 94,43, Stomoxys calcitran 10,49 dan Musca domestica 7,74.

\section{DAFTAR PUSTAKA}

Borror, D.J., C.A, Triplehorn, N. F. Johnson. 1996. Pengenalan Pelajaran Serangga. Edisi ke-6. Gadjah Mada University Press. Yogyakarta

Bowman, J.S (1999). Performance Apparaisal: $\quad$ Verisimilitude trumps veracity. Public Perdonnel Managemen. 
Direktorat Jenderal Peternakan dan Kesehatan Hewan (Ditjennak). 2014. Pemerintah Pusat dan Daerah Berkomitmen Melaksanakan Pembangunan Peternakan dan Kesehatan Hewan Nasional. [Online]. Tersedia: http://ditjennak.pertanian.go.id (Diakses: 1 September 2016)

Foil, L.D. dan J.A. Hogsette. 1994. Biology and control of tabanids, stable flies, and horn flies. Rev Sci Tech Off Int Epiz. 13(4):1125-1158.

Hadi, U. K. dan S. Soviana 2000. Ektoparasit. Pengenalan Diagnosis dan pengendaliannya. Laboratorium Entomologi. Fakultas Kedokteran Hewan. Institut Pertanian Bogor.

Huang, Y.T., S. Shinonaga, H. Sasaki. 2007. Studies on the muscid flies associated with pasturing cattle and water buffaloes in Taiwan (Diptera: Muscidae). J. Rakuno Gakuen Univ. 32(1):15-20.

Jeanbourquin, P. 2005. The Role of Odour Perception in the Sensory Ecology of The Stable Fly, Stomoxys calcitrans L.Faculte des Sciences Intitut de Zoologie Universite de Neuchatel.
Moon, M.J. 2002. The Evolution of EGovemment among Municipalities: Rhetoric or Reality? dalam Public Administration Review. Blackwell Publishing on behalf of the American Society for Public Admmistration. Vol. 62 (4): 424433. Stable URL: http://www.jstor.org/stable/3110 357 Accessed: 22/02/2010 22:19

Salem, A., M. Franc, P. Jacquiet, E. Bouhsira, E. Liénard. 2012. Feeding and breeding aspects of Stomoxys calcitrans (Diptera: Muscidae). Parasite 19:309-317.

Subyanto dan A. Sultoni. 1991. Kunci Determinasi Serangga, Program Nasional Pelatihan dan Pengembangan Hama Terpadu. Kanisius, Yogyakarta.

Taylor, D.B., R.P. Moon, D.R. Mark. 2012. Economic impact of stable flies (Diptera Muscidae) on dairy and beef cattle production. J. Med Entomol. 49(1):198-209.

Tumrasvin, W. dan S. Shinonaga 1978. Studies on medically important fle $\mathrm{s}$ in Thailand. V. On 32 species belonging to the subfamilies Muscinae and Stomoxyinae including the taxonomic keys (Dipetra Muscidae). Bull Tokyo Med Dent Univ. 25 (4): 201-27. 